\title{
Property Regimes of Spouses and Partners in NEW EU REgulations - JURISDiCTION, Prorogation and Choice of LaW ${ }^{1}$
}

\author{
Lucia Valentová \\ Faculty of Law, Palacký University Olomouc, Czech Republic \\ lucia.valentova@upol.cz
}

VALENTOVÁ, Lucia. Property Regimes of Spouses and Partners in New EU Regulations - Jurisdiction, Prorogation and Choice of Law. International and Comparative Law Review, 2016, vol. 16, no. 2, pp. 221-240. DOI: 10.1515/iclr2016-0026.

\begin{abstract}
Summary: There are millions of international couples living and working in the EU. Not a small number of those face difficult time when their marriage or partnership comes to an end. On top of dealing with loss, the couples have to navigate through a lot of administrative and legal obstacles to figure out the division of their property located in different Member States or governed by different national law. These proceedings are lengthy and expensive. European Commission, aware of the issue their citizens face, introduced two proposals for regulations on matrimonial property and property of registered partners. In 2013 the proposals did not get the required unanimity, in 2016 they are being re-introduced in enhanced cooperation.
\end{abstract}

Keywords: Regulation, enhanced cooperation, property, marital property, registered partners, jurisdiction, applicable law, enforcement.

\section{Opening Remarks}

The death of a spouse or a divorce is a difficult time for anyone. Citizens should not be burdened even more by complicated administrative or legal procedures that cost time and money. As more and more people fall in love, marry or create partnerships across borders, clear rules are needed to decide how joint property is divided in case of death, divorce or separation. ${ }^{2}$ This is a statement from the European Commission's press release on $2^{\text {nd }}$ of March 2016 introducing two proposals for regulations concerning issues of matrimonial property and property of the register partners hoping this time around, after a significant

1 This article was created with contribution from the Grant Agency of the Czech Republic for the grant No 16-10589S Foreign dispute resolution clauses - their validity and enforcement by Czech national courts.

2 EUROPEAN COMMISSION. Property effects of marriage and registered partnership [online]. ec.europa.eu, 29. 9. 2016 [cit. 30. October 2016]. Available at $<$ http://ec.europa. eu/justice/civil/family-matters/marriage/index_en.htm>. 
compromise, the regulations aiming to save the time and money of international couples will get adopted by the Parliament and the Council.

\section{Introduction}

The European Union has under the art. 81 para 1 of the Treaty on Functioning of the European Union, further "TFEU", the competence to develop judicial cooperation in civil matters having cross-border implications, based on the principle of mutual recognition of judgments and of decisions in extrajudicial cases. Such cooperation may include the adoption of measures for the approximation of the laws and regulations of the Member States. In family law issues with crossborder implications, however, the legislation has to undergo a special legislative procedure and that is that the Council shall act unanimously after consulting the European Parliament. ${ }^{3}$ The issues, that the Commission has seen as one of the most problematic for some time, is the division of the property in case of death of one spouse and when the marriage ends up in divorce or in legal separation. Because there are 28 different national point of views on the joint property division, this issue was difficult not only from creation of the rules point of view but even more so from the point of the adoption process. The situation is even more complicated when the property that is supposed to be divided belongs to the registered partners. It is because of this complexity that the Commission had to introduce the new regulations twice.

The European Commission proposals aim to clarify the property rights for international married couples or registered partnerships. The Commission wishes that the regulations will establish clear rules in cases of divorce or separation and bring an end to parallel and possibly conflicting proceedings in various Member States, for instance on property or bank accounts. By enabling the married international couples to choose the law that applies to their property in case of death or divorce, enhancing legal certainty for registered partnerships with an international dimension, by submitting the joint property to the law of the country where the partnership was registered, bringing legal certainty for international couples, married or in registered partnerships, through a coherent set of rules for identifying which country's court is responsible and which law will apply and by increasing the predictability for couples by smoothing out the process for recognizing judgments, decisions and titles throughout the EU, the

3 Art. 81 para 3 TFEU - Notwithstanding paragraph 2, measures concerning family law with cross-border implications shall be established by the Council, acting in accordance with a special legislative procedure. The Council shall act unanimously after consulting the European Parliament. The Council, on a proposal from the Commission, may adopt a decision determining those aspects of family law with cross-border implications which may be the subject of acts adopted by the ordinary legislative procedure. The Council shall act unanimously after consulting the European Parliament. The proposal referred to in the second subparagraph shall be notified to the national Parliaments. If a national Parliament makes known its opposition within six months of the date of such notification, the decision shall not be adopted. In the absence of opposition, the Council may adopt the decision. 
regulations will ultimately bring more legal clarity for international couples. Still the Commission needed to stress out that the regulations do not harmonize or change any of the substantive national laws on marriage or registered partnerships and are not aiming to push a sensitive agenda too hard. ${ }^{4}$

\section{International Level}

Property regimes of spouses have always been a question that the international community had to dealt with. Usually in connection with marriage itself but always as a part of the complex family law issues. Even national lawmakers are trying to adopt national rules to new trends and offer spouses and partners various regimes and modification. ${ }^{5}$ Mainly the Hague Conference on International Private Law produced two conventions that touched this area. 1905 Hague convention concerning conflict of laws relating to the effects of marriage on the rights and duties of spouses in their personal relations and on their property and 1978 Hague Convention on the law applicable to matrimonial property regimes.

1905 Hague Convention only dealt with law applicable to the personal relations and property of the spouses. The contracting parties were Germany, Belgium, France, Italy, The Netherlands, Poland and free city of Gdansk, Portugal, Romania and Sweden. The Convention went to effect in all states by the end February 1915 and then all the Contracting States stepped out of the treaty by the August 1987.

The 1978 Convention also dealt exclusively with applicable law to matrimonial property regimes and was based on the principle of universality. ${ }^{6}$ Although the principle of universality seemed promising for creation of an international cooperation and understanding, only a few states became the Contracting states. For Austria and Portugal, the Convention never came into effect and that left only France, Luxemburg and The Netherlands to cooperate.

The latest 2005 Convention on Choice of Courts Agreements in its art. 2 para 2 letter c) expressly excludes other family law matters, including matrimonial property regimes and other rights or obligations arising out of the marriage or similar relationships out of its scope of application. It is safe to conclude that there is no international cooperation in this matter at the moment. So to create the harmonized cooperation is of great importance as well of great difficulty.

4 EUROPEAN COMMISSION. Property effects of marriage and registered partnership [online]. ec.europa.eu, 29. 9. 2016 [cit. 30. October 2016]. Available at $<$ http://ec.europa. eu/justice/civil/family-matters/marriage/index_en.htm>.

5 Check COUPLES IN EUROPE. The law for couples in the $27 \mathrm{EU}$ countries [online]. coupleseurope.eu, 2012 [cit. 30. October2016]. Available at <http://www.coupleseurope.eu/en/ home>.

6 According to Art. 2 the convention applies even if the nationality or the habitual residence of the spouses or the law to be applied by virtue of the following articles is not that of a contracting state. 


\section{European Law Level}

\subsection{History}

The adoption of European legislation on matrimonial and partners' property regimes was among the priorities identified in the 1998 Vienna Action Plan. The programme on mutual recognition of decisions in civil and commercial matters was adopted by the Council in late November 2000. ${ }^{7}$ The Hague programme which was adopted by the European Council three years later, set the implementation of the mutual recognition programme as a top priority and called on the Commission to submit a Green Paper on 'the conflict of laws in matters concerning matrimonial property regimes, including the question of jurisdiction and mutual recognition, and stressed the need to adopt legislation by 2011. In 2003 research on these issues was conducted also on the academic level as requested by the Commission mostly thanks to the TMC Asser Institute and Département de droit international of the Catholic University of Leuven (UCL). ${ }^{9}$ The Stockholm Programme, which was adopted by the European Council in December 2009, also stated that mutual recognition must be extended to matrimonial property regimes and the property consequences of the separation of unmarried couples. In the 'EU Citizenship Report 2010: Dismantling the obstacles to EU citizens' rights, ${ }^{10}$ adopted on 27 October 2010, the Commission identified uncertainty surrounding the property rights of international couples as one of the main obstacles faced by EU citizens in their daily lives when they tried to exercise the rights the EU conferred on them across national borders. To remedy this, it was announced that the Commission would adopt in 2011 a proposal for legislation to make it easier for international couples, either married or registered partners, to know which courts had jurisdiction to deal with their property rights and which law applied to their property rights. A group of experts, PRM/III, was set up by the Commission to draw up the proposal. The group was made up of

7 EUROPEN COMMUNUTIES. Official Journal L 12 Volume 44 [online]. ec.europa.eu, 16. 1. 2001 [cit. 30. October 2016]. Available at <http://eur-lex.europa.eu/legal-content/CS/ ALL/?uri=OJ:L:2001:012:TOC>.

8 EUROPEAN COMMISSION. Communication from the Commission to the Council, the European Parliament, the European Economic and Social Committee and the Committee of the Regions Justice, Freedom and Security in Europe Since 2005: an Evaluation of The Hague Programme and Action Plan [online]. eur-lex.europa.eu, 10. 6. 2009 [cit. 30. October 2016]. Available at $<$ http://eur-lex.europa.eu/legal-content/EN/TXT/PDF/?uri=CELEX:52009D C0263\&from $=$ cs $>$.

9 BRUNO, Giorgio. Commission's Proposals On Matrimonial Property Regimes and Property Consequences of Registered Partnerships [online]. conflictsoflaws.net, 24. 3.2011 [cit. 30. October 2016]. Available at <http://conflictoflaws.net/2011/commissions-proposalson-matrimonial-property-regimes-and-property-consequences-of-registered-partnerships/>.

10 EUROPEAN COMMISSION. EU Citizenship Report 2010 [online]. ec.europa.eu, 21. 10. 2010 [cit. 30. October 2016]. Available at <http://ec.europa.eu/justice/citizen/files/ com_2010_603_en.pdf >. 
experts representing the range of professions concerned and the different European legal traditions. It met five times between 2008 and 2010. The Commission also held a public hearing on $28^{\text {th }}$ September 2009 involving some hundred participants. The debates confirmed the need for an EU instrument for matrimonial property regimes that covered in particular applicable law, jurisdiction and the recognition and enforcement of decisions. A meeting with national experts was held in March 2010 to discuss the thrust of the proposal being drafted. ${ }^{11}$

On $16^{\text {th }}$ March 2011, the Commission finally adopted proposals for a Council Regulation on jurisdiction, applicable law and the recognition and enforcement of decisions in matters of matrimonial property regimes ${ }^{12}$ and a for a Council Regulation on jurisdiction, applicable law and the recognition and enforcement of decisions regarding the property consequences of registered partnerships. ${ }^{13}$ The proposals related to judicial cooperation in civil matters covering 'aspects relating to family law' where the Council has to act unanimously after consulting the European Parliament. The European Parliament delivered its opinion on $10^{\text {th }}$ September $2013^{14}$ and the Commission proposals were discussed in the Council Working Party on Civil Law Matters until the end of 2014. In December 2014, the Council decided to grant a reflection period to those Member States which continued to have difficulties for a single year. At its meeting on $3^{\text {rd }}$ December 2015, the Council concluded that no unanimity could be reached for the adoption of the proposals for regulations on matrimonial property regimes and the property consequences of registered partnerships and that therefore the objectives of cooperation in this area could not be attained within a reasonable period by the Union as a whole. ${ }^{15}$

11 BRUNO, Giorgio. Commission's Proposals On Matrimonial Property Regimes and Property Consequences of Registered Partnerships [online]. conflictsoflaws.net, 24. 3. 2011 [cit. 30. October 2016]. Available at <http://conflictoflaws.net/2011/commissions-proposalson-matrimonial-property-regimes-and-property-consequences-of-registered-partnerships/>.

12 EUROPEAN COMMISSION. Proposal for a Council Regulation on jurisdiction, applicable law and the recognition and enforcement of decisions in matters of matrimonial property regimes [online]. ec.europe.eu, 16. 3. 2011 [cit. 30. October 2016]. Available at $<$ http://eurlex.europa.eu/LexUriServ/LexUriServ.do?uri=COM:2011:0126:FIN:en:PDF>.

13 EUROPEAN COMMISSION. Proposal for a Council Regulation on jurisdiction, applicable law and the recognition and enforcement of decisions regarding the property consequences of regisered partnership [online]. ec.europe.eu, 16. 3. 2011 [cit. 30. October 2016]. Available at <http://eur-lex.europa.eu/LexUriServ/LexUriServ.do?uri=COM:2011:0127:FIN:en:PDF>.

14 EUROPEAN COMMISSION. Proposal for a Council Regulation on jurisdiction, applicable law and the recognition and enforcement of decisions in matters of matrimonial property regimes [online]. ec.europe.eu, 16. 3. 2011 [cit. 30. October 2016]. Available at $<$ http://eurlex.europa.eu/LexUriServ/LexUriServ.do?uri=COM:2011:0126:FIN:en:PDF>.

15 Explanatory Report to EUROPEAN COMMISSION. Proposal for a Council Regulation on jurisdiction, applicable law and the recognition and enforcement of decisions in matters of matrimonial property regimes [online]. ec.europe.eu, 16. 3. 2011 [cit. 30. October 2016]. Available at <http://eur-lex.europa.eu/LexUriServ/LexUriServ.do?uri=COM:2011:012 6:FIN:en:PDF>. and EUROPEAN COMMISSION. Proposal for a Council Regulation on 
Although it seemed as unsuccessful attempt the Council noted that several Member States expressed their readiness to give positive consideration to the establishment of at least enhanced cooperation on the matters covered by the proposals. ${ }^{16}$ From December 2015 to February 2016, 17 Member States, namely Sweden, Belgium, Greece, Croatia, Slovenia, Spain, France, Portugal, Italy, Malta, Luxembourg, Germany, the Czech Republic, the Netherlands, Austria, Bulgaria and Finland, addressed a request to the Commission indicating that they wished to establish enhanced cooperation between themselves in the area of the property regimes of international couples and, specifically, of jurisdiction, applicable law and the recognition and enforcement of decisions in matters of matrimonial property regimes and jurisdiction, applicable law and the recognition and enforcement of decisions regarding the property consequences of registered partnerships, and asking the Commission to submit a proposal to the Council to that effect.

The proposal for a Council Decision contained a detailed assessment of the legal conditions governing, and the appropriateness of, the introduction of enhanced cooperation in the area of jurisdiction, applicable law and the recognition and enforcement of decisions on the property regimes of international couples, covering both matters of matrimonial property regimes and the property consequences of registered partnerships.

Even the Vice-President Frans Timmermans and the EU Justice Commissioner Verra Jourová stated, that the regulations represent legal certainty for thousands of European couples notwithstanding whether they are married or in registered partnerships. With regulations being only applicable in form of enhanced cooperation the rules will only help a fraction of international couples, ${ }^{17}$ but it is certainly a progress. The EU Justice Commissioner added that the international couples face a difficult situation when their relationship comes to an end and it is not made any less easy for them when they need to deal with burdensome administrative procedures and unclear legal situations concerning often their

jurisdiction, applicable law and the recognition and enforcement of decisions regarding the property consequences of regisered partnership [online]. ec.europe.eu, 16. 3. 2011 [cit. 30. October 2016]. Available at $<$ http://eur-lex.europa.eu/LexUriServ/LexUriServ.do?uri=CO M:2011:0127:FIN:en:PDF>.

16 Enhanced cooperation allows a group of at least nine member states to implement measures if all 28 Member States fail to reach agreement. Other EU countries keep the right to join when they want (Article 331 TFEU).

1717 Member States have requested enhanced cooperation to adopt this legislation. They represent $67 \%$ of EU population, and a majority of international couples who live in the European Union. The non-participating Member States will continue to apply their national law (including their rules on private international law) to cross-border situations dealing with matrimonial property regimes and the property consequences of registered partnerships. 
houses and livelihoods. The regulations pave the way for those Member States willing to go forward with this important initiative. ${ }^{18}$

\subsection{Challenges}

The questions that the Commission posed were rather serious. What will happen to your home, when you get divorced and your husband is of different nationality? What will happen to your joined bank account when your spouse dies? What will happen when you and your partner have the same nationality but you have property and accounts abroad?

Nonexistence of adequate answers to these questions was the decisive impulse for the European Union. Giving the fact that the marriage as an institute is recognized in all 28 Member States and 9 of those, namely the Netherlands, Belgium, France, Denmark, Luxembourg, the United Kingdom (England and Wales), Spain, Sweden and Portugal, recognize marriage between two persons of the same sex and that the registered partnership exists in regulation of 18 Member States, precisely Austria, Belgium, Croatia, the Czech Republic, Denmark, Germany, Finland, France, Greece, Hungary, Ireland Luxembourg, Malta, Netherlands, Slovenia, some regions of Spain, Sweden and the United Kingdom and Belgium, France, Luxembourg, Malta and the Netherlands allow for registered partnership even between two persons of different sex, the clear rules on joint property of spouses and partners is a factor to consider when ensuring the fundamental rights of EU citizens, mainly the freedom to move and reside. ${ }^{19}$

Even though the numbers are clear every single time when EU introduced new regulation that could potentially touch the issue of spousal and partner property, the legislator chose to exempt property rights and regime from their

18 EUROPEAN COMMISSION. Commission goes ahead with 17 Member States to clarify the rules applicable to property regimes for Europe's international couples [online]. europa.eu, 2. 3. 2006 [cit. 30. October 2016]. Available at <http://europa.eu/rapid/press-release_IP-16449_en.htm>.

19 Art. 20 TFEU Citizenship of the Union is hereby established. Every person holding the nationality of a Member State shall be a citizen of the Union. Citizenship of the Union shall be additional to and not replace national citizenship. 2. Citizens of the Union shall enjoy the rights and be subject to the duties provided for in the Treaties. They shall have, inter alia: (a) the right to move and reside freely within the territory of the Member States; (b) the right to vote and to stand as candidates in elections to the European Parliament and in municipal elections in their Member State of residence, under the same conditions as nationals of that State; C 326/56 EN Official Journal of the European Union 26.10.2012 (c) the right to enjoy, in the territory of a third country in which the Member State of which they are nationals is not represented, the protection of the diplomatic and consular authorities of any Member State on the same conditions as the nationals of that State; (d) the right to petition the European Parliament, to apply to the European Ombudsman, and to address the institutions and advisory bodies of the Union in any of the Treaty languages and to obtain a reply in the same language. These rights shall be exercised in accordance with the conditions and limits defined by the Treaties and by the measures adopted thereunder. 
scope of application. In case of Brussels I bis regulation ${ }^{20}$ art. 1 para 2 letter a) states that this regulation shall not apply to the status or legal capacity of natural persons, rights in property arising out of a matrimonial relationship or out of a relationship deemed by the law applicable to such relationship to have comparable effects to marriage. Brussels II bis's ${ }^{21}$ art. 1 para 3 letter $\mathrm{f}$ ) exempts trusts or succession from the scope of application and finally Regulation on succession ${ }^{22}$ does not deal with questions relating to matrimonial property regimes and property regimes of relationships deemed by the law applicable to such relationships to have comparable effects to marriage as stated by art. 1 para 2 letter $\mathrm{d}$ ).

The fact that majority of Member states recognize registered partnership and all of them regulate marriage is not as pressing as the actual statistics that show how relevant this issue is. Out of 16 million international couples at least 650000 deal with issues of property distribution every day. According to data from 2007, 2,4 million new marriages were entered into and $13 \%$, around 310000 , out of them were with international element. Number of registered partnerships oscillates around 211000 out of which 19,5\%, 41000 , were with international element. 8,500 partnerships were dissolved by separation, 1,266 ended by death of one of the parties. To resolve all of the disputes estimated 1,1 billon EURO had to be spent. The Commission proposes to reduce the cost of litigation by one third. ${ }^{23}$

So far the typical case involving property dispute with international element unfolds like this. A Hungarian man and his Greek wife got married in Greece and lived there for three years after the wedding, then moved to Hungary where the marriage failed after a further two years. In this case, it is not clear whether Greek or Hungarian laws would cover the division of the couple's property. The liquidation of the matrimonial regime was governed by Greek substantive law under the Greek conflict of law rule (common habitual residence of the spouses at the time of marriage), whereas it is governed by Hungarian substantive law under the Hungarian conflict of law rule (common habitual residence of the

20 Regulation (EU) No 1215/2012 of the European Parliament and of the Council of 12 December 2012 on jurisdiction and the recognition and enforcement of judgments in civil and commercial matters (recast).

21 Regulation (EC) No 2201/2003 of 27 November 2003 concerning jurisdiction and the recognition and enforcement of judgments in matrimonial matters and the matters of parental responsibility, repealing Regulation (EC) No 1347/2000.

22 Regulation (EU) No 650/2012 of the European Parliament and of the Council of 4 July 2012 on jurisdiction, applicable law, recognition and enforcement of decisions and acceptance and enforcement of authentic instruments in matters of succession and on the creation of a European Certificate of Succession.

23 EUROPEAN COMMISSION. Commission proposes clearer property rights for Europe's 16 million international couples [online]. europa.eu, 16. 3. 2011 [cit. 30. October 2016]. Available at <http://europa.eu/rapid/press-release_IP-11-320_en.htm >. 
spouses at the time of divorce). How will the property regime be regulated with absence of harmonized rules? ${ }^{24}$

Without regulation, the complexity of property distribution proceedings manifest itself also in its lengthy. The Commission provides an example of twenty years of legal proceedings when a Spanish citizen married a man with double nationality: Dutch and German. The couple got married in Düsseldorf (Germany) in 1965. Their matrimonial property was (automatically) governed by a community regime; both spouses were aware of this. For cultural and practical purposes, the Spanish wife changed her nationality, after marriage, from Spanish to Dutch and the couple moved to the Netherlands. They owned property both in Germany and in Spain. At the time of the divorce, both parties had their habitual residence in the Netherlands and were of Dutch nationality, and therefore the proceedings took place in the Netherlands. During the divorce proceedings, the parties agreed that the husband would keep the property in Germany whilst the wife would keep the property in Spain, an agreement that was formalised by a letter signed by the husband confirming that he passed on the ownership rights of the Spanish property to his ex-wife. However, before the conclusion of the divorce the wife had to move back to Spain for health reasons and established her habitual residence there. This had unintended consequences when she decided, a year after the divorce, to name their children as the legal owners of the property in Spain. As she started the procedures for the transfer of the property rights, she discovered that she needed her ex-husband's consent to do so because she had been married under the community of property regime and the letter drafted by her ex-husband (which would have been sufficient to transfer property under Dutch law) was not recognised in Spain. The case came to an end after twenty years of legal proceedings and fees after her ex-husband agreed to sign before a notary a document transferring the property ownership rights to the children. ${ }^{25}$

\subsection{Proposed Regulations}

The both regulations have the same structure. After preamble, scope and definitions, the regulations give rules on the jurisdiction. In the Proposal for a Council Regulation on jurisdiction, applicable law and the recognition and enforcement of decisions in matters of matrimonial property regimes the rules on jurisdiction are divided into three categories based on the reason for dissolution of the marriage. In event of the death of one of the spouses the court determined in accordance with Regulation (EU) No 650/2012 on matters of the

24 EUROPEAN COMMISSION. Clearer property rights for Europe's 16 million international couples - frequently asked questions [online]. europa.eu, 16. 3. 2011 [cit. 30. October 2016]. Available at $<$ http://europa.eu/rapid/press-release_MEMO-11-175_en.htm >.

25 EUROPEAN COMMISSION. Clearer property rights for Europe's 16 million international couples - frequently asked questions [online]. europa.eu, 16. 3. 2011 [cit. 30. October 2016]. Available at <http://europa.eu/rapid/press-release_MEMO-11-175_en.htm>. 
succession shall have jurisdiction to rule on matters of the matrimonial property regime arising in connection with that succession case. ${ }^{26}$

If the dissolution of the marriage is a result of divorce, legal separation or marriage annulment the proposed regulation connects the proceedings on property with proceedings on divorce, legal separation or marriage annulment under Brussels IIbis Regulation (EC) No 2201/2003. ${ }^{27}$ Jurisdiction in matters of matrimonial property regimes shall be subject to the spouses' agreement where the court that is seized to rule on the application for divorce, legal separation or marriage annulment is the court of a Member State in which the applicant is habitually resident and he or she resided there for at least a year immediately before the application was made ${ }^{28}$ or is the court of a Member State of which the applicant is a national and the applicant is habitually resident there and resided there for at least six months immediately before the application was made, ${ }^{29}$ or it is the court determined under Article 5 of Regulation (EC) No 2201/2003 in cases of conversion of legal separation into divorce, or is seized under Article 7 of Regulation (EC) No 2201/2003 in cases of residual jurisdiction. The spouses have to agree on the jurisdiction of court determined after art. 5 of the proposed regulation. If the agreement is concluded before the court is seized to rule on matters of matrimonial property regimes, the agreement shall comply with rules on prorogation of the court.

When no courts of a Member State has jurisdiction according to above mentioned rules, especially in cases where the marriage is not being dissolved, e.g. when the spouses are merely altering their property regime, jurisdiction to rule on a matter of the spouses' matrimonial property regime shall lie with the courts of the Member State either in whose territory the spouses are habitually resident at the time the court is seized, or failing that in whose territory the spouses were last habitually resident, insofar as one of them still resides there at the time the court is seized, or failing that in whose territory the respondent is habitually

26 Art. 4 EUROPEAN COMMISSION. Proposal for a Council Regulation on jurisdiction, applicable law and the recognition and enforcement of decisions in matters of matrimonial property regimes [online]. ec.europe.eu, 16. 3. 2011 [cit. 30. October 2016]. Available at <http://eur-lex.europa.eu/LexUriServ/LexUriServ.do?uri=COM:2011:0126:FIN:en:PDF>.

27 Art. 5 EUROPEAN COMMISSION. Proposal for a Council Regulation on jurisdiction, applicable law and the recognition and enforcement of decisions in matters of matrimonial property regimes [online]. ec.europe.eu, 16. 3. 2011 [cit. 30. October 2016]. Available at <http://eur-lex.europa.eu/LexUriServ/LexUriServ.do?uri=COM:2011:0126:FIN:en:PDF>.

28 In accordance with Article 3 (1) (a) fifth indent of Regulation (EC) No 2201/2003 of 27 November 2003 concerning jurisdiction and the recognition and enforcement of judgments in matrimonial matters and the matters of parental responsibility, repealing Regulation (EC) No 1347/2000 (Regulation Brussels IIbis).

29 In accordance with Article 3 (1) (a) sixth indent of Regulation (EC) No 2201/2003 of 27 November 2003 concerning jurisdiction and the recognition and enforcement of judgments in matrimonial matters and the matters of parental responsibility, repealing Regulation (EC) No 1347/2000 (Regulation Brussels IIbis). 
resident at the time the court is seized and finally there, where is the common nationality of the spouses' at the time the court is seized. ${ }^{30}$

Newly the spouses may consent on a court they wish will have the jurisdiction over their property case. This prorogation is allowed only in cases where the marriage is not dissolved because of the death of the spouse, divorce legal separation or marriage annulment. Thus only in cases covered by Article 6, the parties may agree that the courts of the Member State whose law is applicable in accordance with Articles 22, 26 (1) (a) or (b) or the courts of the Member State of the celebration of the marriage shall have exclusive jurisdiction to rule on matters of their matrimonial property regime. The Articles 22, 26 para 1 letter a) or b) point to courts of Member State where the spouses or future spouses, or one of them, is habitually resident at the time the agreement is concluded, or Member State of nationality of either spouse or future spouse at the time the agreement is concluded. Furthermore, spouses may choose the courts of Member State of the spouses' first common habitual residence after the celebration of the marriage or, failing that of the spouses' common nationality at the time of the celebration of the marriage. The agreement on choice of court has to be expressed in writing and dated and signed by the parties. Any communication by electronic means which provides a durable record of the agreement shall be deemed equivalent to writing.

The proposal of the regulation in matters of matrimonial property regimes further regulates jurisdiction based on the appearance of the defendant, alternative jurisdiction, subsidiary jurisdiction, forum necessitatis rule, counterclaims, limitation in proceedings, seizing the court, examination as to jurisdiction and admissibility, lis pendens, related actions and provisional including protecting measures. $^{31}$

Above interesting is the question of alternative jurisdiction. Since the proposal of the regulation on matrimonial property regimes is merely in enhanced cooperation, the regulation foresees that the national private international law may not recognise the marriage in question for the purposes of matrimonial regime proceedings. It is only by the way of the exception, but the court that would have had the jurisdiction according to art. 4 to 8 may decline its jurisdiction based on the non-recognition of the marriage. If the court decides to do so, it shall do it without undue day. Where a court having jurisdiction under Articles 4 or 6 declines jurisdiction and where the parties agree to confer jurisdiction to

30 Art. 6 EUROPEAN COMMISSION. Proposal for a Council Regulation on jurisdiction, applicable law and the recognition and enforcement of decisions in matters of matrimonial property regimes [online]. ec.europe.eu, 16. 3. 2011 [cit. 30. October 2016]. Available at <http://eur-lex.europa.eu/LexUriServ/LexUriServ.do?uri=COM:2011:0126:FIN:en:PDF>.

31 EUROPEAN COMMISSION. Proposal for a Council Regulation on jurisdiction, applicable law and the recognition and enforcement of decisions in matters of matrimonial property regimes [online]. ec.europe.eu, 16. 3. 2011 [cit. 30. October 2016]. Available at $<$ http://eurlex.europa.eu/LexUriServ/LexUriServ.do?uri=COM:2011:0126:FIN:en:PDF>. 
the courts of any other Member State in accordance with Article 7, jurisdiction to rule on matrimonial property regime shall lie with the courts of that Member State. In other cases, jurisdiction to rule on the matrimonial property regime shall lie with the courts of any other Member State under Articles 6, 8 or the courts of the Member State of the celebration of the marriage.

As to the applicable law the regulation is based on the principle of universality and unity. ${ }^{32}$ The unity in this case means that the law applicable to a matrimonial property regime under Articles 22 or 26 shall apply to all assets falling under that regime, regardless of their location. The regulation prefers spouses or future spouses to choose the applicable law to their property regime provided that it is the law of the State where the spouses or future spouses, or one of them, is habitually resident at the time the agreement is concluded, or the law of a State of nationality of either spouse or future spouse at the time the agreement is concluded. Spouses may decide to change the law applicable on their property regime during the marriage. The regulation allows spouses to agree otherwise, however the change of the law applicable to the matrimonial property regime made during the marriage shall have prospective effect only. ${ }^{33}$ Any retroactive change of the applicable law shall however not adversely affect the rights of third parties deriving from that law. ${ }^{34}$

In the absence of a choice-of-law agreement, the law applicable to the matrimonial property regime shall be the law of the State of the spouses' first common habitual residence after the celebration of the marriage or, if there is no such State, the law of State of the spouses' common nationality at the time of the celebration of the marriage or, failing that, with which the spouses jointly have the closest connection at the time of the celebration of the marriage, taking into account all the circumstances. If the spouses have more than one common nationality at the time of the celebration of the marriage, the law of State of common nationality rule cannot be applied.

By way of exception and upon application by either spouse, the court having jurisdiction to rule on matters of the matrimonial property regime may decide that the law of a State other than the State whose law is applicable shall govern

32 Art. 20 and 21 EUROPEAN COMMISSION. Proposal for a Council Regulation on jurisdiction, applicable law and the recognition and enforcement of decisions in matters of matrimonial property regimes [online]. ec.europe.eu, 16. 3. 2011 [cit. 30. October 2016]. Available at $<$ http://eur-lex.europa.eu/LexUriServ/LexUriServ.do?uri=COM:2011:0126:FIN:en:PDF>.

33 Art. 22 para 2 EUROPEAN COMMISSION. Proposal for a Council Regulation on jurisdiction, applicable law and the recognition and enforcement of decisions in matters of matrimonial property regimes [online]. ec.europe.eu, 16. 3. 2011 [cit. 30. October 2016]. Available at $<$ http://eur-lex.europa.eu/LexUriServ/LexUriServ.do?uri=COM:2011:0126:FIN:en:PDF>.

34 Art. 22 para 3 EUROPEAN COMMISSION. Proposal for a Council Regulation on jurisdiction, applicable law and the recognition and enforcement of decisions in matters of matrimonial property regimes [online]. ec.europe.eu, 16.3. 2011 [cit. 30. October 2016]. Available at $<$ http://eur-lex.europa.eu/LexUriServ/LexUriServ.do?uri=COM:2011:0126:FIN:en:PDF>. 
the matrimonial property regime if the applicant demonstrates that the spouses had their last common habitual residence in that other State for a significantly longer period of time than in the State the application of art 26 para 1 letter a pointed at and that the both spouses had relied on the law of that other State in arranging or planning their property relations. The law of that other State shall apply as from the celebration of the marriage, unless one spouse disagrees. In the case of disagreement, the law of that other State shall have effect as from the establishment of the last common habitual residence in that other State. This rule however shall not be used, when the spouses have concluded a matrimonial property agreement before the establishment of their last common habitual residence in that other State.

Apart from the rules on choice of law and law applicable with absence of the choice, the regulations introduces provisions on formal validity of the agreement on a choice of applicable law, consent and material validity, formal validity of a matrimonial property agreement and scope of the applicable law, that shall determine among other the classification of property of either or both spouses into different categories during and after marriage, the transfer of property from one category to the other, the responsibility of one spouse for liabilities and debts of the other spouse, the powers, rights and obligations of either or both spouses with regard to property, the dissolution of the matrimonial property regime and the partition, distribution or liquidation of the property, the effects of the matrimonial property regime on a legal relationship between a spouse and third parties, and the material validity of a matrimonial property agreement. The regulation does not omit to regulate effects in respect of third parties, adaptation of rights in rem, overriding mandatory provisions, public policy, exclusion of renvoi, territorial conflicts of laws, inter-personal conflicts of laws and nonapplication of the Regulation to internal conflicts of laws. ${ }^{35}$

When regulating the process of recognition, enforceability and enforcement of the decisions under the proposed regulation, the EU lawmaker choose to link this procedure to the recognition and enforcement under regulation 650/2012. ${ }^{36}$ A decision given in a Member State shall be recognised in the other Member States without any special procedure being required. ${ }^{37}$ Naturally the regulation

35 EUROPEAN COMMISSION. Proposal for a Council Regulation on jurisdiction, applicable law and the recognition and enforcement of decisions in matters of matrimonial property regimes [online]. ec.europe.eu, 16. 3. 2011 [cit. 30. October 2016]. Available at $<$ http://eurlex.europa.eu/LexUriServ/LexUriServ.do?uri=COM:2011:0126:FIN:en:PDF>.

36 Explanatory Report to EUROPEAN COMMISSION. Proposal for a Council Regulation on jurisdiction, applicable law and the recognition and enforcement of decisions in matters of matrimonial property regimes [online]. ec.europe.eu, 16. 3. 2011 [cit. 30. October 2016]. Available at $<$ http://eur-lex.europa.eu/LexUriServ/LexUriServ.do?uri=COM:2011:0126:FI $\mathrm{N}: \mathrm{en}: \mathrm{PDF}>$.

37 Art. 36 para 1 EUROPEAN COMMISSION. Proposal for a Council Regulation on jurisdiction, applicable law and the recognition and enforcement of decisions in matters of matrimonial property regimes [online]. ec.europe.eu, 16.3.2011 [cit. 30. October 2016]. Available at 
in subsequent article offers grounds for non-recognition, which are the same as in all EU regulations, namely, that the recognition is manifestly contrary to public policy in the Member State in which recognition is sought, the decision was given in default of appearance under said circumstances, it is irreconcilable with a decision given in proceedings between the same parties in the Member State in which recognition is sought or with an earlier decision given in another Member State or in a third State involving the same cause of action and between the same parties, provided that the earlier decision fulfils the conditions necessary for its recognition in the Member State in which recognition is sought. ${ }^{38}$ Further the regulation provides rules for prohibition of review of jurisdiction of the court of origin and to the substance of the decision, enforceability and determination of domicile, declaration of enforceability, appeal against the decision on the application for a declaration of enforceability, legal aid and interestingly a provision of art. 38 on fundamental rights. The regulation states expressly that the rules on recognition shall be applied by the courts and other competent authorities of the Member States in observance of the fundamental rights and principles recognised in the Charter of Fundamental Rights of the European Union, in particular Article 21 thereof on the principle of non-discrimination. ${ }^{39}$

The Proposal for a Council Regulation on jurisdiction, applicable law and the recognition and enforcement of decisions in matters of the property consequences of registered partnerships is quite similar to the proposed regulation on matrimonial property issues with few differences in jurisdiction and applicable law rules. Firstly, since the area of the registered partnership and its legal implications is new and complex, the regulation provides definitions of key terms. All of these are meant to be interpreted autonomously for the purposes of the regulation. ${ }^{40}$ The EU is not forcing any new regulation on the Member States. The proposed regulation for example understands under the notion ,registered partnership' the regime governing the shared life of two people which is pro-

<http://eur-lex.europa.eu/LexUriServ/LexUriServ.do?uri=COM:2011:0126:FIN:en:PDF>.

38 EUROPEAN COMMISSION. Proposal for a Council Regulation on jurisdiction, applicable law and the recognition and enforcement of decisions in matters of matrimonial property regimes [online]. ec.europe.eu, 16. 3. 2011 [cit. 30. October 2016]. Available at $<$ http://eurlex.europa.eu/LexUriServ/LexUriServ.do?uri=COM:2011:0126:FIN:en:PDF>.

39 Art 21 of the Charter of Fundamental Rights of the European Union - Non-discrimination Any discrimination based on any ground such as sex, race, colour, ethnic or social origin, genetic features, language, religion or belief, political or any other opinion, membership of a national minority, property, birth, disability, age or sexual orientation shall be prohibited. 2. Within the scope of application of the Treaty establishing the European Community and of the Treaty on European Union, and without prejudice to the special provisions of those Treaties, any discrimination on grounds of nationality shall be prohibited.

40 Explanatory Report to EUROPEAN COMMISSION. Proposal for a Council Regulation on jurisdiction, applicable law and the recognition and enforcement of decisions regarding the property consequences of regisered partnership [online]. ec.europe.eu, 16. 3. 2011 [cit. 30. October 2016]. Available at <http://eur-lex.europa.eu/LexUriServ/LexUriServ.do?uri=CO M:2011:0127:FIN:en:PDF>. 
vided for in law, the registration of which is mandatory under that law and which fulfils the legal formalities required by that law for its creation and by ,property consequences of a registered partnership the set of rules concerning the property relationships of the partners, between themselves and in their relations with third parties, as a result of the legal relationship created by the registration of the partnership or its dissolution. ${ }^{41}$

In case that the registered partnership is dissolved on grounds of death of one of the partners, the jurisdiction to rule on matters of the property consequences of the registered partnership arising in connection with that succession case will according to art. 4 lie with the court seized under provisions of regulation on succession. So in this case the both regulation follow the same pattern. Going on further it is no longer possible. When the property consequences of the registered partnership are based on dissolution or annulment of the partnership, the proposed regulation cannot link the jurisdictions based on the rules of Brussels IIbis regulation. The EU has deal with this issue by stating that where a court of a Member State is seized to rule on the dissolution or annulment of a registered partnership the courts of that State shall have jurisdiction to also rule on the property consequences of the registered partnership arising in connection with that case of dissolution or annulment, where the partners so agree. The agreement has to be concluded before the court is seized and shall comply with rules on prorogation. ${ }^{42}$

In all other case the jurisdiction to rule on the property consequences of a registered partnership shall lie with the courts of the Member State in whose territory the partners are habitually resident at the time the court is seized, or failing that in whose territory the partners were last habitually resident, insofar as one of them still resides there at the time the court is seized, if there is no such court than in whose territory the respondent is habitually resident at the time the court is seized, or failing that, of the partners' common nationality at the time the court is seized. The last option when the court cannot be determined by any of the rules above, the jurisdiction will lie under whose law the registered partnership was created. Moreover, in all of these cases the parties may agree that the courts of the Member State whose law is applicable in accordance with Articles 22 or 26 para 1 or the courts of the Member State under whose law the registered

41 Art 3 para 1 letters a) and b) EUROPEAN COMMISSION. Proposal for a Council Regulation on jurisdiction, applicable law and the recognition and enforcement of decisions regarding the property consequences of registered partnership [online]. ec.europe.eu, 16. 3. 2011 [cit. 30. October 2016]. Available at <http://eur-lex.europa.eu/LexUriServ/LexUriServ.do? uri=COM:2011:0127:FIN:en:PDF>.

42 Art. 5 EUROPEAN COMMISSION. Proposal for a Council Regulation on jurisdiction, applicable law and the recognition and enforcement of decisions regarding the property consequences of registered partnership [online]. ec.europe.eu, 16. 3. 2011 [cit. 30. October 2016]. Available at <http://eur-lex.europa.eu/LexUriServ/LexUriServ.do?uri=COM:2011:0127:FI $\mathrm{N}: e n: P D F>$. 
partnership was created shall have exclusive jurisdiction to rule on the property consequences of their registered partnership. The prorogation of the jurisdiction is for the registered partners' property distribution linked to the courts of the State where the partners or future partners, or one of them, is habitually resident at the time the agreement is concluded, or the law of a State of nationality of either partner or future partner at the time the agreement is concluded, or the law of the State under whose law the registered partnership was created. The agreement the partners will concluded in order to choose the preferable court shall be expressed in writing and dated and signed by the parties. Any communication by electronic means which provides a durable record of the agreement shall be deemed equivalent to writing. ${ }^{43}$

Apart from the jurisdiction based on the appearance, the proposal for regulation on property of registered partners follows the regulation on matrimonial property also with regulation of alternative jurisdiction. If the Member State, whose courts' would have had jurisdiction under the regulation does regulate the institution of registered partnership, it may decline its jurisdiction without undue delay. The parties again may with accordance to rules on prorogation confer jurisdiction to the courts of another available Member State. In other cases, jurisdiction to rule on the property consequences of a registered partnership shall lie with the courts of any other Member State under rules on jurisdiction in other cases and jurisdiction based on appearance. ${ }^{44}$

Especially for the regulation on partners' property the art. 9 para 3 gives a rule that excludes application of this article as whole when the parties have obtained a dissolution or annulment of a registered partnership which is capable of recognition in the Member State of the forum. The wording "capable of recognition" follows the articles 33-34 of Brussels Ibis regulation. This rule is guarantying the access to justice for the registered partners and is preventing Member States to claim public policy exception in situation where they de facto have recognized the partnership when giving the decision on its annulment or dissolution.

As to the regulation of applicable law the partners or future partners have according to art. 22 right to designate or to change law of the Member Stat that law attaches the property consequences to the institution of the registered partnership and that it is the law of the State where the partners or future partners,

43 Art. 6 EUROPEAN COMMISSION. Proposal for a Council Regulation on jurisdiction, applicable law and the recognition and enforcement of decisions regarding the property consequences of registered partnership [online]. ec.europe.eu, 16. 3. 2011 [cit. 30. October 2016]. Available at $<$ http://eur-lex.europa.eu/LexUriServ/LexUriServ.do?uri=COM:2011:0127:FI $\mathrm{N}$ :en:PDF>.

44 Art. 8 EUROPEAN COMMISSION. Proposal for a Council Regulation on jurisdiction, applicable law and the recognition and enforcement of decisions regarding the property consequences of registered partnership [online]. ec.europe.eu, 16. 3. 2011 [cit. 30. October 2016]. Available at <http://eur-lex.europa.eu/LexUriServ/LexUriServ.do?uri=COM:2011:0127:FI $\mathrm{N}: \mathrm{en}: \mathrm{PDF}>$. 
or one of them, is habitually resident at the time the agreement is concluded or the law of a State of nationality of either partner or future partner at the time the agreement is concluded, or finally the law of the State under whose law the registered partnership was created. The partners may again change the law during the course of their registered partnership but they have to mind the rights of third parties deriving from that law.

If the partners do not choose the applicable law, the law applicable to the property consequences of registered partnerships shall be the law of the State under whose law the registered partnership was created. Out of this general rule, there is an exception the partners have to apply for. The court having jurisdiction to rule on matters of the property consequences of a registered partnership may decide that the law of other Member State shall govern the property consequences of the registered partnership if the law of that other State attaches property consequences to the institution of the registered partnership and if the applicant demonstrates that the partners maintained their last common habitual residence in that State for a significantly long period of time and that they both had relied on the law of that other State in arranging or planning their property relations. The law shall then apply as from the creation of the registered partnership, unless one partner disagrees. In that case the law of that other State shall have effect as from the establishment of the last common habitual residence in that other State. Application of this exception may not adversely affect the rights of third parties deriving from the law of the Member State where the partnership was created, unless the partners have concluded a partnership property agreement before the establishment of their last common habitual residence in that Member State.

In the rest of the Regulation on matrimonial property and partners property match. The reason why the Commission submitted two proposals for two separate regulations is however in the difference in features and legal impact of matrimonial property and property of registered partners. ${ }^{45}$

\section{Ordre Public Guarantees}

Controversy of the subject matters of the regulations caused the impossibility to reach unanimity among all 28 Member states. Denmark in accordance with Articles 1 and 2 of the Protocol on the position of Denmark ${ }^{46}$ did not take part in the adoption of the proposed Regulation and is therefore not bound by it nor

45 Explanatory Report to EUROPEAN COMMISSION. Proposal for a Council Regulation on jurisdiction, applicable law and the recognition and enforcement of decisions regarding the property consequences of regisered partnership [online]. ec.europe.eu, 16. 3. 2011 [cit. 30. October 2016]. Available at $<$ http://eur-lex.europa.eu/LexUriServ/LexUriServ.do?uri=CO M:2011:0127:FIN:en:PDF>.

46 THE LISBON TREATY. Protocol on the Position of Denmark [online]. lisbon-treaty.org [cit. 30. October 2016]. Available at <http://www.lisbon-treaty.org/wcm/the-lisbon-treaty/ protocols-annexed-to-the-treaties/851-protocol-on-the-position-of-denmark-851.html $>$. 
it is a subject to its application. In accordance with Article 1 and 2 of Protocol on the position of the United Kingdom and Ireland ${ }^{47}$ the both countries did not give notice of their wish to take part in the adoption and application of the proposed Regulation. Other Member States are free to join the regulations if they decide to do so.

The principle of universal application of the Regulations may however point to the law of a non-cooperating Member State, as well as any rule on jurisdiction except of the lex loci celebrationis, manly the alternative jurisdiction rule. These rules allow for a Member State that does not have national legislation regulating matrimonial property regimes in particularly formed marriages and moreover does not recognize registered partnership or even more, it is contrary to its public policy, to face another Member States court's decision on this issue forcing it to act.

Many Member States, who objected against the first regulations and who are not cooperating on the second, expressed concerns about their public policy and demanded guarantees that no regulation will be forced upon them and they would not have to recognize and enforce decisions in issues they do not regulate. ${ }^{48}$

In case of Slovakia, who is not cooperating, the representation at European Commission advocated for guarantees in respect of both regulations. In case of matrimonial property regimes Slovakia demanded that from the scope of application will be the issues of existence, validity or recognition of a marriage. The definition of "marriage“ is to be left to national systems of the Member States. Slovakia firmly stands on position, that valid marriage may occur only between a man and a woman. ${ }^{49}$ If in front of a Slovak court a decision of another Member State on matrimonial property regime arising from the marriage, which, according to Slovak regulations is not valid (e.g. the spouses are of the same sex or the marriage was entered in by a minors, polygamous marriage etc.), the regulation has to allow the court to decline jurisdiction. Slovak courts cannot be forced to decide on property regimes of marriage, which, according to the Slovak law, do not exist. Spouses from such unrecognized marriage would have to resolve

47 THE LISBON TREATY. Protocol on the Position of the United Kingdom and Ireland in respect of the Area of Freedom, Security and Justice [online]. lisbon-treaty.org [cit. 30. October 2016]. Available at < http://www.lisbon-treaty.org/wcm/the-lisbon-treaty/protocolsannexed-to-the-treaties/669-protocol-on-the-position-of-the-united-kingdom-and-ireland-in-respect-of-669.html>.

48 VNUKOVÂ, Jana. Niektoré aspekty navrhovanej úpravy majetkových režimov manželov a registrovaných partnerov navrhovaná v Evropskej Únii. In LENHART, Michal, GIBA, Marián et al. (eds.) Milníky práva v Stredoeurópskom priestore. Bratislava: Univerzita Komenského v Bratislave Právnická fakulta, 2016, s. 121-126.

49 See ALIANCIA ZA RODINU. Rodina je najdôležitejšia hodnota v Európe, ale ... [online]. alianciazarodinu.sk [cit. 30. October2016]. Available at <http://www.alianciazarodinu.sk/ preco-chranit-rodinu/>. 
property regime at a court other than Slovak. If a foreign court decision is subsequently seeking recognition in the Slovak Republic, the recognition and enforcement of such decision on matrimonial property regimes will not mean recognition of the marriage by that decision. This guarantee will mean that Slovak courts will not have to acknowledge the existence of another Member State's marriages in Slovak territory. The recognition is necessary only with respect to the related property rights.

In case of property consequences of registered partnerships, Slovak representation advocated again that the existence, validity or recognition of a registered partnership will be excluded from the scope and demanded that Member State, whose law does not regulate registered partnerships, is not forced by the regulation to include and regulated registered partnership in its national law. If one of the parties would like to sue on the property consequences of registered partnerships in Slovakia, the courts would have had the right to decline the jurisdiction. Slovak court is not obliged to rule on the property consequences of registered partnerships, as this institute does not exist in the Slovak law. If a party would seek to recognize and enforce a foreign court decision in the Slovak Republic, recognition and enforcement of that decision on the property consequences of registered partnerships does not imply recognition of registered partnership by the decision..$^{50}$

Simply put, Slovakia, along with other traditional Member States, needed to be ensure that it will keep the right to decline jurisdiction or recognition and enforcement of any court decision on matrimonial property in case of marriages that are contrary to the Slovak public policy and property of registered partners since this issue is not even regulated. Even though there is undeniable proof of thousands of international couples that are not deemed to be traditional, some Member States didn't want to be pressured by the European Union to recognize foreign court decision based on these relationships and indirectly recognizing this forms as having legal consequences but didn't want to closed the door to potential cooperation as well.

\section{Conclusion}

Migration is a backbone of the EU Single market. Freedom to move and reside freely in the territory of the Member States is protected under art. 20 para 2 letter a) of TFEU. It is, however, difficult for the citizens of EU truly freely move within EU when relationships with international element, which are inherently part of the choice to live outside of the Member State of one's habitual residence,

50 VNUKOVÁ, Jana. Niektoré aspekty navrhovanej úpravy majetkových režimov manželov a registrovaných partnerov navrhovaná v Evropskej Únii. In LENHART, Michal, GIBA, Marián et al. (eds.) Milníky práva v Stredoeurópskom priestore. Bratislava: Univerzita Komenského v Bratislave Právnická fakulta, 2016, s. 124. 
are so difficult, time consuming and expensive to resolve when they get complicated.

The European Union tries to react on the most pressing issues and presents more and more regulations and directives that should simplify court proceedings and ensure access to justice. After the rules on jurisdiction, enforcement and recognition in civil and commercial matters, matrimonial matters, maintenance obligations, issues of inheritance and law applicable on divorce and separation of the marriage, the European Union tried to face another obstacle in matrimonial property regimes and property of registered partners and didn't fail, but didn't succeeded.

The proposals for new regulation should enter into force in 2017 and without doubt bring more legal certainty to international couples, at least the most of them. European Union is unable in recent years ${ }^{51}$ to present crucial regulations in family law matters that would reach unanimity and truly regulate and harmonize rules for international couples. It times when the whole world is in crisis of the values the European Union is not leading by example.

Regulations, even as enhanced cooperation, on matrimonial property regimes and property regimes of registered partners are indisputably a step forward. They are a result of careful compromise and when upholding their public policy guarantees, they may one day transfer to fully binding regulations. At this point it is safe to say that they are a great achievement in the field of international cooperation on property matters.

51 See for example Council Regulation (EU) No 1259/2010 of 20 December 2010 implementing enhanced cooperation in the area of the law applicable to divorce and legal separation. 